\title{
Pedagogical conditions for training of future ship engineers in the process of English for specific purpose learning
}

\author{
Yurzhenko A.* \\ Maritime college of Kherson State Maritime Academy, Kherson, Ukraine
}

Received: 22.12.2018 Accepted: 26.12 .2018

\begin{abstract}
The article describes and analyzes the pedagogical conditions of forming the communicative competence of future ship engineers. Analysis of literary sources shows that the problem of determining the pedagogical conditions for the training of future ship engineers in the process of studying the English language for professional purpose becomes of particular importance. In our study, pedagogical conditions that most effectively influence the formation of ship engineers' readiness are identified and characterized in the article, namely: provision of positive motivation of cadets to study activities in the process of studying the English language for professional purpose; the introduction of a gamification approach (the use of game techniques in a non-gaming environment to obtain certain results, in our case - the acquisition of communicative competence) in the system of training future ship engineers by means of the information and communication pedagogical environment (platform MOODLE); development and implementation of the author's interactive electronic teaching-methodical complex of the discipline "English language for professional purpose". In order to determine the optimal pedagogical conditions for professional training of future ship engineers in the process of studying English was taken into account the specificity of learning (selection and systematization of the content of educational material, interest in teaching and professional activities, the ability of cadets to study - the features of thinking, memory, etc.). Positive motivation will encourage cadets to develop their desire to study and to find satisfaction in the learning process. The introduction of a gamification approach to learning will help to break out learning games and game techniques (tournament tables, game exercises, badges, quests, progression loops, etc.). Implementation of the author's interactive electronic teaching and learning complex of the discipline "English for professional purpose" will facilitate the formation of future English engineers' communicative competency for performing professional tasks on board a vessel. In order to achieve the goal, we consider it expedient to use the latest technologies, including the MOODLE distance learning platform, the gamification approach, the systems of blended learning and the communicative approach.
\end{abstract}

Key words: communicative competence, gamification approach, LMS MOODLE, English for professional purpose, ship engineers.

\section{Педагогічні умови підготовки майбутніх суднових механіків у процесі вивчення англійської мови за професійним спрямуванням

\author{
Юрженко А. Ю.
}

\author{
Морський коледж Херсонської Державної Морської Академії, Херсон, Україна
}

\begin{abstract}
Анотація. У статті означено та проаналізовано педагогічні умови фрормування комунікативної компетентності майбутніх суднових механіків. Аналіз літературних джерел показує, що проблема визначення педагогічних умов підготовки майбутніх суднових механіків у процесі вивчення англійської мови за професійним спрямуванням набуває особливого значення. У нашому дослідженні виокремлено та охарактеризовано педагогічні умови, які найбільш ефективно впливатимуть на формування готовності суднових механіків, а саме: забезпечення позитивної мотивацію курсантів до навчальної діяльності у процесі вивчення англійської мови за професійним спрямуванням; запровадження гейміфікованого підходу (використання ігрових методик у неігровому середовищі задля отримання певних результатів, у нашому випадку - оволодіння комунікативною компетентністю) у системі професійної підготовки майбутніх суднових механіків засобами інформаційно-комунікативного педагогічного середовища (платформи MOODLE); розробка та впровадження авторського інтерактивного електронного навчально-методичного комплексу дисципліни «Англійська мова за професійним спрямуванням». Задля визначення оптимальних педагогічних умов проф. підготовки майбутніх суднових механіків у процесі вивчення англійської мови було
\end{abstract}

Corresponding Author: Yurzhenko Alona Yurivna. Tel. +380999018138. E-mail: helen18@online.ua Maritime college of Kherson State Maritime Academy, 83 Robocha str., Kherson, Ukraine, 73001.

Відповідальний автор: Юрженко Альона Юріївна. Тел. +380999018138. E-mail: helen18@online.ua Морський коледж Херсонської Державної Морської Академії, вул. Робоча, 83, м. Херсон, Україна, 73001. 
враховано специфіку навчання (відбір та систематизація змісту навчального матеріалу, інтерес до навчальнопрофесійної діяльності, здатності студентів до навчання - особливості мислення, пам'яті, тощо). Позитивна мотивація сприятиме розвитку у курсантів бажання вчитися та знаходити задоволення в процесі навчання. Запровадження гейміфікованого підходу до навчання допоможе розвести навчання іграми та ігровими методиками (турнірними таблицями, ігровими вправами, бейджиками, квестами, шкалою виконання, тощо). Впровадження авторського інтерактивного електронного навчально-методичного комплексу дисципліни «Англійська мова за професійним спрямуванням» сприятиме формуванню у майбутніх суднових механіків англомовної комунікативної компетентності для виконання професійних завдань на судні. Задля досягнення мети, ми вважаємо доцільним використання новітніх технологій, зокрема платформи дистанційного навчання MOODLE, гейміфікованого підходу, системи змішаного навчання та комунікативного підходу.

Ключові слова: комунікативна компетентність, гейміфікований підхід, LMS MOODLE, англійська мова за професійним спрямуванням, суднові механіки.

\title{
Педагогические условия подготовки будущих судовых механиков в процессе изучения английского языка профессиональной направленности
}

\author{
Юрженко А. Ю. \\ Морской колледж Херсонской Государственной Морской Академии, Херсон, Украина
}

\begin{abstract}
Аннотация. В статье отмечены и проанализированы педагогические условия формирования коммуникативной компетентности будущих судовых механиков. Анализ литературных источников показывает, что проблема определения педагогических условий подготовки будущих судовых механиков в процессе изучения английского языка профрессиональной направленности приобретает особое значение. В нашем исследовании выделены и охарактеризованы педагогические условия, которые наиболее эфффективно влиять на формирование готовности судовых механиков, а именно: обеспечение положительной мотивации курсантов к учебной деятельности в процессе изучения английского языка профессиональной направленности; введение геймифициированного подхода (использование игровых методик в неигровой среде для получения определенных результатов, в нашем случае - овладения коммуникативной компетентностью) в системе профессиональной подготовки будущих судовых механиков средствами информационнокоммуникативного педагогической среды (платформы MOODLE); разработка и внедрение авторского интерактивного электронного учебно-методического комплекса дисциплины «Английский язык профессиональной направленности». Для определения оптимальных педагогических условий проф. подготовки будущих судовых механиков в процессе изучения английского языка было учтена специфика обучения (отбор и систематизация содержания учебного материала, интерес к учебно-профессиональной деятельности, способности студентов к обучению - особенности мышления, памяти и т.д.). Положительная мотивация способствует развитию у курсантов желание учиться и находить удовольствие в процессе обучения. Введение геймифицированного подхода к обучению поможет развести обучение играми и игровыми методиками (турнирными таблицами, игровыми упражнениями, бейджиками, квестами, шкалой выполнения и т.д.). Внедрение авторского интерактивного электронного учебно-методического комплекса дисциплины «Английский язык профессиональной направленности» будет способствовать формированию у будущих судовых механиков англоязычной коммуникативной компетентности для выполнения профессиональных задач на судне. Для достижения цели, мы считаем целесообразным использование новейших технологий, в частности платформы дистанционного обучения MOODLE, геймифицированного подхода, системы смешанного обучения и коммуникативного подхода.
\end{abstract}

Ключевые слова: коммуникативная компетентность, геймифицированный подход, LMS MOODLE, английский язык профессиональной направленности, судовые механики.

\section{Bcmyn}

У наш час значно зросла потреба ринку праці у кваліфікованому фахівці, який би відповідав вимогам сучасного роботодавця. Проблема формування комунікативної компетентності майбутніх суднових механіків - це підготовка фрахівця, здатного виконувати професійні завдання на судні за допомогою англійської мови, яка $€$ робочою мовою судна. Отже, постала проблема формування професійної комунікативної компетентності майбутніх фахівців морської галузі, що обумовлюється обґрунтуванням та реалізацією певних педагогічних умов [1].

Мета нашої роботи - означити та проаналізувати педагогічні умови фрормування комунікативної компетентності майбутніх суднових механіків 


\section{II Матеріал і методи дослідження}

Для поліпшення якості підготовки англійської мови майбутніх суднових механіків одним із варіантів вирішення цієї проблеми ми вбачаємо у створенні педагогічних умов проф. підготовки під час вивчення АМ (англійської мови).

У філософрській думці поняття «умова» розглядається як фрілософрська категорія, в якій відображаються універсальні по відношенню до тих факторів, завдяки яким вона виникає та існує.

Педагогіка використовує два взаємопов'язаних поняття: «педагогічні умови» та «дидактичні умови», сутність цих понять доповнюють один одного.

Шерман М.І. розглядає концептуальний, цільовий, змістовий, технологічний, результативнооцінний компоненти як комплекс педагогічних умов і засобів [2].

Дендеренко О.О. у своїй праці про формування професійної компетентності майбутніх суднових механіків у процесі інтеграції природничих і загальнотехнічних дисциплін, визначив психологопедагогічних умов, які впливають на результативність формування професійної компетентності майбутніх суднових механіків у процесі вивчення природничих і загальнотехнічних дисциплін [3]. Науковець також окреслив наступні психолого-педагогічні умови:

- дотримання принципів наступності, професійної спрямованості навчання, поєднанні репродуктивного і продуктивного підходів до навчання, підвищенні мотивації до навчальної діяльності, поєднанні індивідуальної та групової форм роботи студентів;

- реалізація впливу на компоненти професійної компетентності (когнітивний, діяльнісний, особистісний) шляхом застосування фреймового підходу до засвоєння наукових знань (вплив на когнітивний компонент професійної компетентності);

- застосування інтегративних технологій навчання, які забезпечують вимоги контекстного, інтерактивного та ком'пютерно-орієнтованого навчання студентів, а також підвищення їх пізнавальної активності.

Враховуючи всі аспекти категорії «педагогічні умови» та різні погляди дослідників щодо трактування її сутності нами було обґрунтовано своє визначення цього поняття. Педагогічні умови, спираючись на визначення Дендеренка О.О., ми розуміємо як чинники, які були створені задля успішної реалізації завдань з метою найефективнішого протікання навчального процесу.

Задля визначення оптимальних педагогічних умов проф. підготовки майбутніх суднових механіків у процесі вивчення АМ ми врахували специфіку навчання (відбір та систематизація змісту навчального матеріалу, інтерес до навчально-професійної діяльності, здатності студентів до навчання - особливості мислення, пам'яті, тощо).

У науково-педагогічному дискурсі [4],[5], [6] для позначення професіоналізму спеціаліста використовується термін «професійна компетентність», що трактується сучасними дослідниками як результативно-діяльнісна характеристика особистості фахівця, яка дозволяє йому ставити й ефективно вирішувати професійні завдання у різноманітних професійних ситуаціях.

Підготовка компетентнісного механіка визначається рівнями ссоормованості його компетентностей з усіх дисциплін. Комунікативна компетентність входить до циклу гуманітарної підготовки, до якої відноситься дисципліна «АМ» (за профресійним спрямуванням) [7].

Ефективність процесу формування комунікативної компетентності залежатиме від реалізації наступних вимог: узгодженість матеріалу 3 навчальною програмою дисципліни «АМ за проф. спрямуванням» та його відповідність щодо професійної підготовки майбутніх суднових механіків; відбір професійно-орієнтованого лексичного матеріалу з урахуванням тематики та актуальності, відповідного рівня складності; належна забезпеченість відібраного матеріалу навчально-методичними рекомендаціями та; систематизація лексичного матеріалу, відповідна наочність; підбір, систематизація мовленнєвих вправ на основі професійного матеріалу (включаючи міжнародні морські конвенції та кодекси); створення професійно-орієнтованих реальних життєвих ситуацій на судні [8].

Для того, щоб формування комунікативної компетентності майбутніх суднових механіків відбувалося найефективнішим способом, ми вважаємо доцільним забезпечити позитивну мотивацію курсантів до навчальної діяльності у процесі вивчення англійської мови за професійним спрямуванням за допомогою запровадження гейміфікованого підходу у системі професійної підготовки майбутніх 
суднових механіків засобами інформаційно-комунікативного педагогічного середовища. Гейміфікований підхід - це використання ігрових методик у неігровому середовищі задля отримання певних результатів, у нашому випадку - оволодіння комунікативною компетентністю [9]. Для підтримки інтересу гейміфрікація пропонує різноманітні види діяльностей, а саме: проходження матеріалу занять у вигляді рівнів та місій, отримання балів та відзнак за виконані завдання, список рівнів у вигляді мапи, таблиці лідерів, гейміфіковані вправи (ігри «Як стати міліонером?», «Шибениця», «Кросворд» тощо), шкала виконання, квести.

\section{III Результати}

Розглянемо декілька видів діяльностей окремо. Мапа авторського електронного курсу «Морська англійська мова» дозволяє курсантам, зарахованим на курс, одразу побачити теми, які будуть вивчатися протягом курсу [11].

Кольорова мапа (рис. 1) використовується також з метою ефективного представлення тем курсу, оскільки від цього залежить успішність засвоєння знань і закріплення навичок. Подача матеріалу таким чином з самого початку сприяє появі інтересу та прагнення вчитись у курсантів. Авторський електронний курс складається з п'яти рівнів, що відображають теми. Кожна тема містить десять місійзавдань.

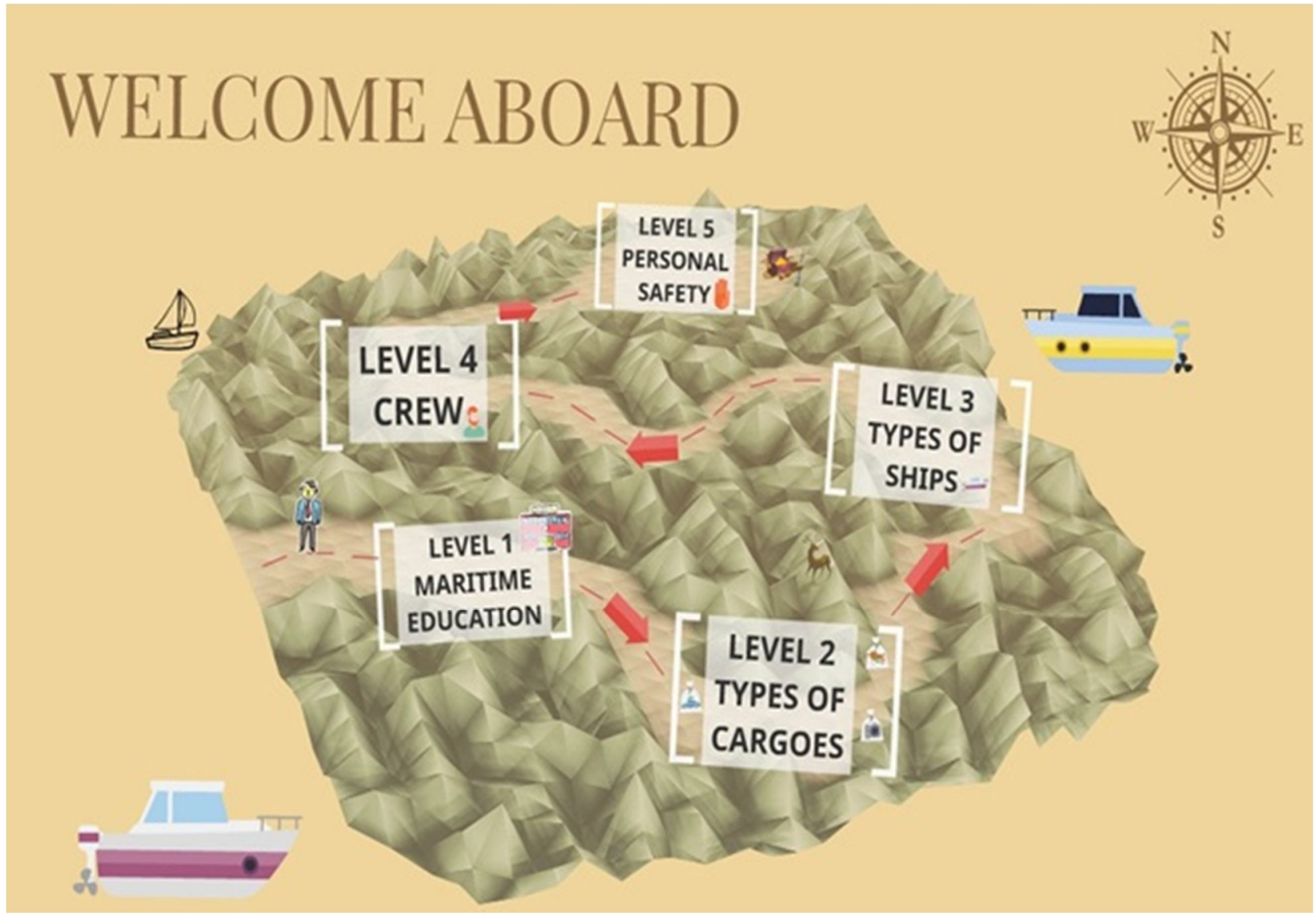

Рис. 1. Мапа курсу «Морська англійська мова», яка відображає назви рівнів курсу

Для отримання позитивного результату на курсі курсант повинен набрати мінімум 60 балів за наступні діяльності (рис. 2):

- 1 рівень: Тест 1 (5 балів) та усна компетенція 1 (10 балів);

- 2 рівень: Тест 2 (5 балів) та усна компетенція 2 (10 балів);

- 3 рівень: Тест 3 (5 балів), усна компетенція 3 (10 балів) та Тест, який містить питання 1го, 2го та Зго рівнів (10 балів);

- 4 рівень: Тест 4 (5 балів) та усна компетенція 4 (10 балів); 
- 5 рівень: Тест 5 (5 балів), усна компетенція 5 (10 балів) та Тест, який містить питання 4го та 5го рівнів (10 балів);

- додаткові бали за виконання таких діяльностей курсу, як презентації, проекти тощо (5 балів).

В сумі всі значимі діяльності курсу складають 100 балів. Набравши 90-100 балів, курсант отримує оцінку 5 за дисципліну «Морська англійська мова». Набравши 70-89, курсант отримує оцінку 4, а набравши 60-69 балів, курсант отримує оцінку 3.

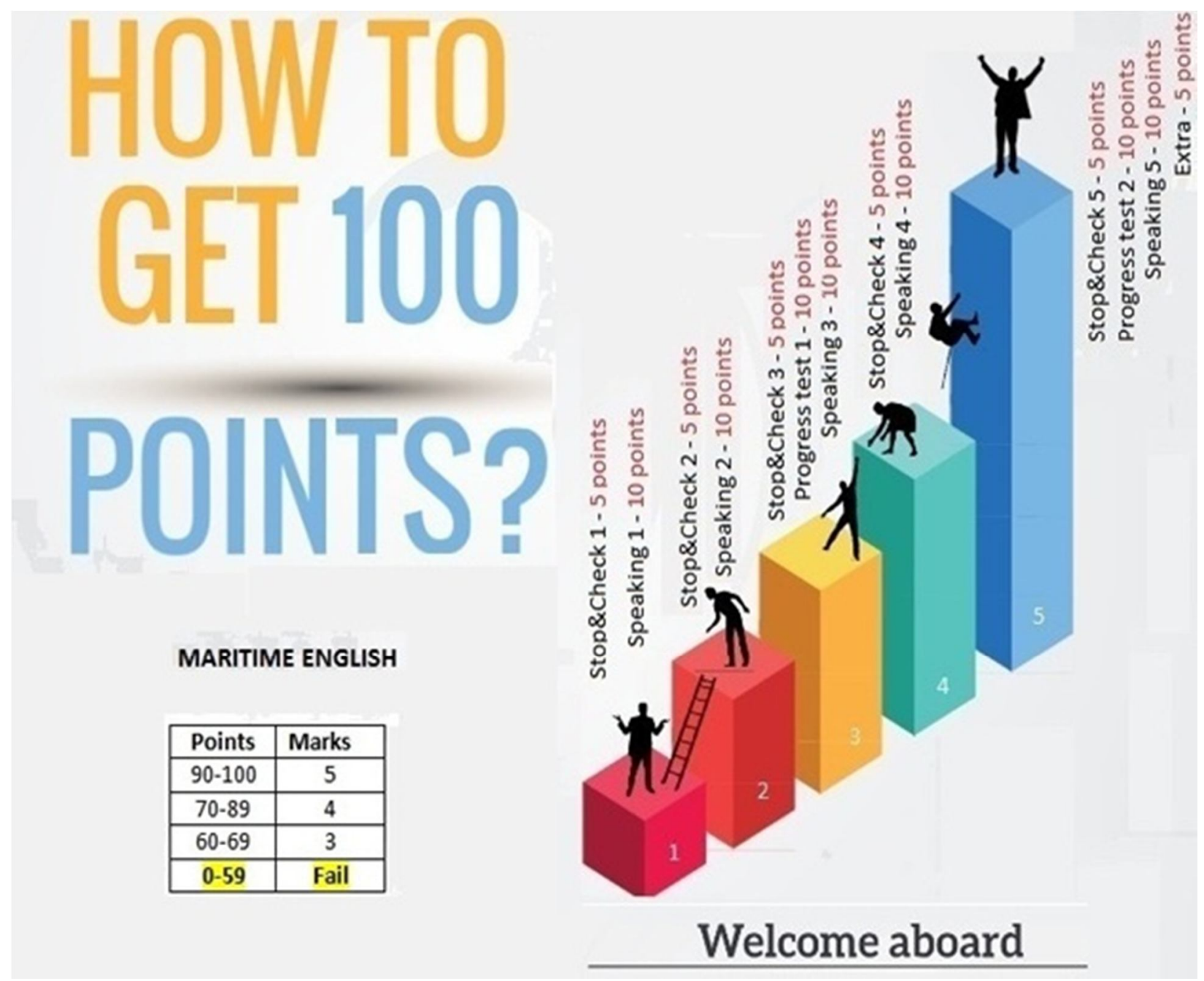

Рис. 2. Інструкція з елементами гейміфрікованого підходу на початку курсу

Шкала виконання (progression loop/bar). Курс морської англійської мови має шкалу виконання, яка допомагає відслідкувати кількість відсотків виконаних діяльностей курсу, візуалізуючи кінцеву ціль навчання (рис. 3) [12].

Maritime English (Юрженко А. Ю.)

$11 \%$

MARITIME ENGLISH COURSE applies to future merchant marine specialists' professional and practical training courses. Maritime English ...

Рис. 3. Шкала виконання діяльностей курсу морської англійської мови 
Таблиці лідерів (leaderboards). Всі важливі діяльності курсу відображаються окремим блоком на курсі, на якому у числовій послідовності показано оцінки та прізвища, ім'я та по батькові курсантів. Ці блоки відображають лідерів та аутсайдерів курсу, змушуючи мотивувати та пробуджуючи інстинкт конкурентної боротьби [13]. Наприклад, на рисунку 4 можна побачити таблицю з курсу, яка відображає чотири найкращі презентації курсантів на тему «Класифікація вантажів».

Гейміфіковані вправи (game-based exercises). Сайт learningapps.org містить 24 шаблони завдань, які можна створити та перенести на курс за допомогою пакету SCORM [14].

Серед шаблонів сайту $є$ шаблони гейміфікованих вправ (рис. 5), наприклад: Wordgrid, Hangman, Horse race, Pairing game, Crossword, Group puzzle, The Millionare game, Multiple choice quiz. Такі інтерактивні, мультимедійні вправи дозволяють підвищити мотивацію учасників курсу до навчання, покращити такі когнітивні функції, як пам'ять та мислення.

\begin{tabular}{|c|c|}
\hline РЕЗУЛЬТАТИ ДІЯЛЬНОСТІ & घ曰 \\
\hline "CLASSIFICATION OF & \\
\hline CARGOES" PRESENTATION & \\
\hline 4 кращих оцінки: & \\
\hline 1. Баркевич Денис Сергійович & 5.00 \\
\hline 2. Білий Данило Дмитровиง & 5,00 \\
\hline $\begin{array}{l}\text { 3. Кандиба Владислав } \\
\text { Романович }\end{array}$ & 5.00 \\
\hline $\begin{array}{l}\text { 4. Комаров Володимир } \\
\text { Володимирович }\end{array}$ & 5,00 \\
\hline
\end{tabular}

Рис. 4. Таблиця «Найкращі презентації» з курсу «Морська англійська мова»

\section{LearningApps.org}

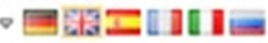

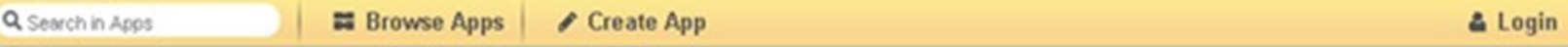
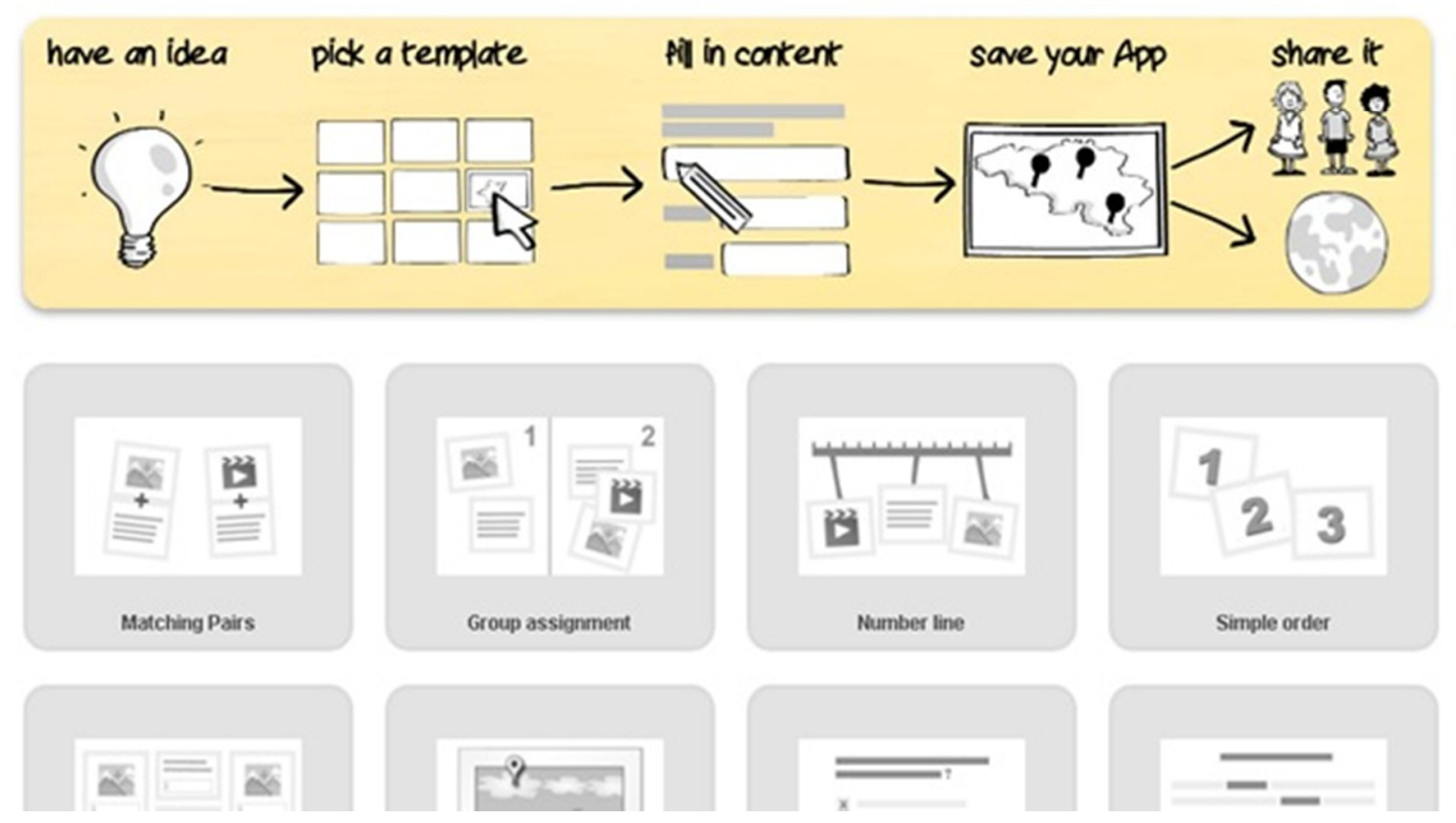

Рис. 5. Шаблони вправ на сайті learningapps.org 


\section{IV Обговорення}

Херсонська державна морська академія працює з платформою MOODLE з 2016 року. Якість та успішність навчання з використанням платформи MOODLE демонструє позитивний тренд порівняно 3 аналогічним періодом у першому кварталі 2015 року. Це можна побачити порівнявши результати тестування (приклад Stop and check 1) у електронній системі (рис. 6) та у письмовому паперовому вигляді, де тест склало 45 курсантів, з них 68\% на задовільно, 21\% на добре та $11 \%$ на відмінно.

\section{Загальна кількість студентів за діапазонами оцінювання}

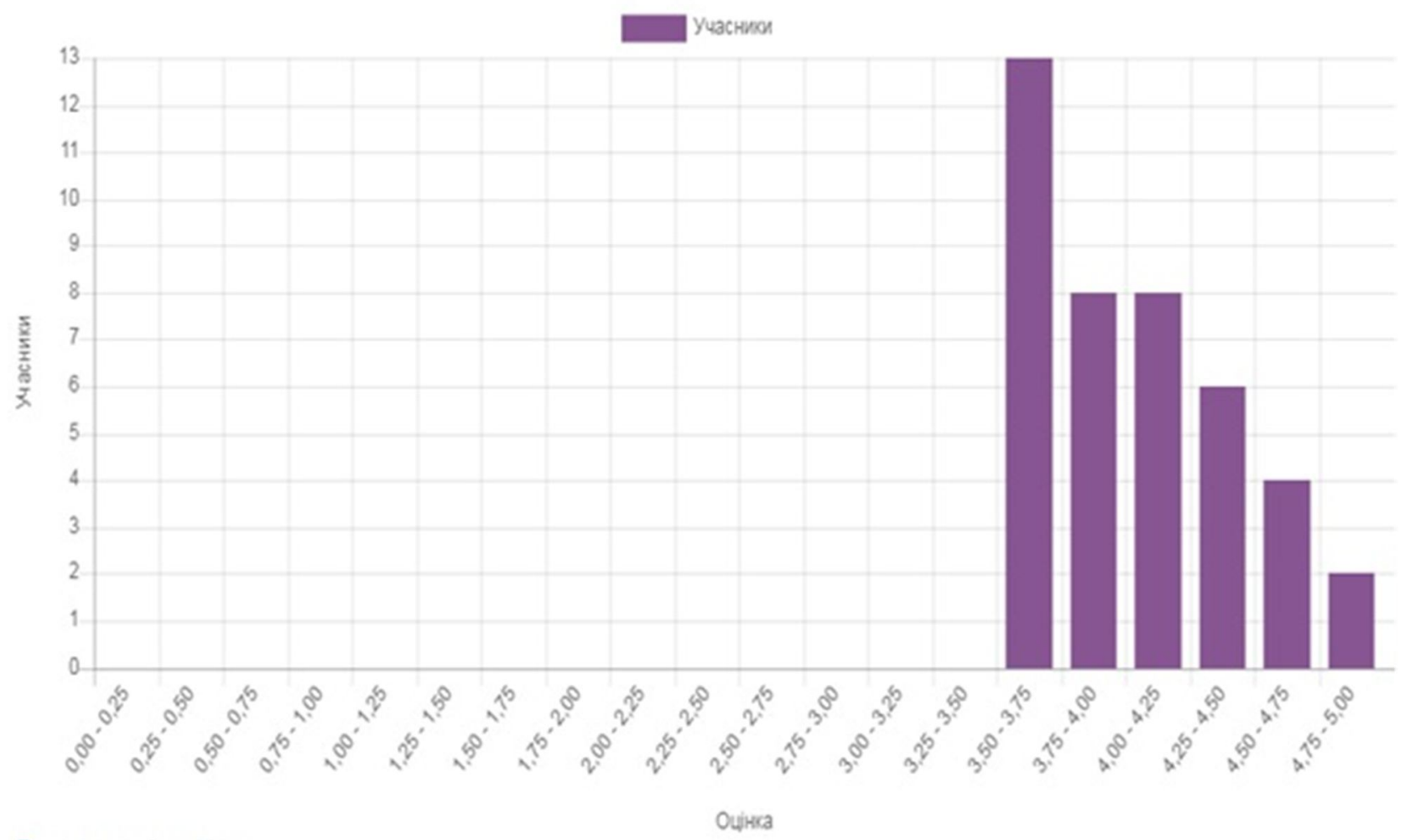

Рис. 6. Статистичні дані з платформі MOODLE за результатами тестової діяльності Stop and check 1

На платформі MOODLE присутня діяльність Обстеження, яка передбачає ряд обстежень корисних при оцінюванні і стимулюванні навчання в дистанційних курсах. Викладач використовує цю діяльність для збору даних про курсантів, дізнаються більше про групи і все це відбивається на подальшому навчанні. Метою даного дослідження $€$ допомогти викладачам зрозуміти, наскільки корисним для курсантів виявилося електронне навчання $[15,16]$. Анкета має 24 твердження, де курсант має порівняти бажання (ідеал) і фактичний досвід у даному питанні. Тут немає 'правильних' чи 'неправильних' відповідей: викладачів цікавить тільки думка опитуваних. Дане анкетування, результати якого ми можемо побачити на рисунку 7 , допомагає поліпшити якість електронного навчання в майбутніх курсах.

Курсанти, заповнивши анкетні дані, відмітили, що в основному навчання фокусується на темах, які їх цікавлять, будуть корисними в професійній практиці та можуть вдосконалити професійні навички $[17,18]$.

Навчаючись в Херсонській державній академії, ми використовуємо систему змішаного навчання (гармонійне поєднання електронного навчання із навчанням у класі). В класі курсанти вивчають морську англійську мову за допомогою компетентнісно-комунікативного підходу з урахуванням досвіду курсантів та рівня їх англомовних комунікативних умінь. Електронний курс на платформі MOODLE вони застосовують в основному вдома, виконуючі домашні завдання, самостійні роботи, творчі завдання (проекти, презентації, квести, тощо), тестові завдання для поточного модульного контролю (Stop \& Check Tests) та для проміжного атестаційного контролю (Progress Tests) [19, 20]. 


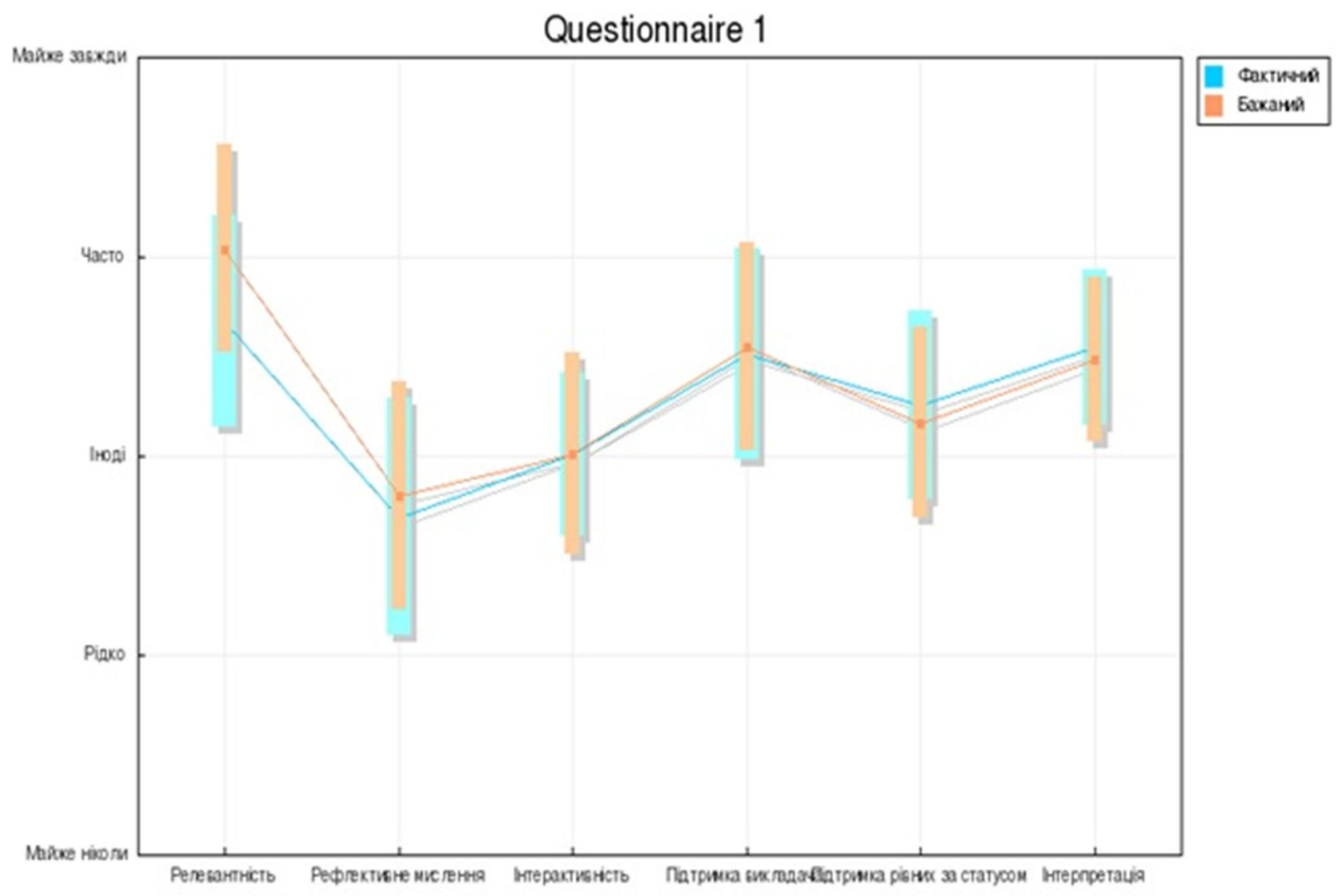

Рис. 7. Діяльність Обстеження на платформі MOODLE

У подальшій роботі над електронними курсами морської англійської мови заплановано вивчення та впровадження базових компонентів глибокого навчання (deep learning), які дозволяють курсантам розвивати суттєві компетентності, необхідні для морських спеціалістів сьогодення.

На думку адміністрації Херсонської державної морської академії саме курси на платсоормі Moodle дозволяють реалізувати усі прийняті в закладах вищої освіти України алгоритми і правила розрахунку підсумкових оцінок за змістовні модулі, модулі, семестри і дисципліну в цілому.

\section{V Висновки}

Таким чином, щоб фрормування комунікативної компетентності майбутніх суднових механіків відбувалося найефективнішим способом, ми вважаємо доцільним використання гейміфрікованого підходу, формування мотивації, впровадження авторських електронних курсів на базі платформи MOODLE. Використання інноваційних технологій (інформаційно-комунікативного педагогічного середовища, гейміфрікованого підходу, технологій web 2.0 (наприклад, вправи з сайту learningapps.org)) дозволяє мотивувати, покращити пам'ять, розвинути критичне мислення тощо.

\section{Бібліографрічні посилання}

[1] Kylouskova N. La compétence de communication / Brno, 2001. P. 33-38.

[2] Шерман М.І., Безбах О. М. Інформаційна культура майбутніх інженерів-судноводіїв як психолого-педагогічний феномен / Зб. наук. праць ХНТУ Актуальні проблеми державного управління, педагогіки та психології. Херсон, 2014. Вип.1 (10). С. 190-193.

[3] Дендеренко 0.О. Формування професійної компетентності суднового механіка шляхом впровадження міждисциплінарної інтеграції фізичних знань. / Матеріали Міжнародної науково-практичної конференції "Актуальні проблеми природничо-наукової освіти в середній і вищий школі". Херсон : ПП В.С. Вишемирський, 2014. С. 137-139.

[4] Колот А. М. Мотивація персоналу : підручник. К. : КНЕУ, 2005. 337 с.

[5] Галацин К.О. Моделювання процесу формування комунікативної культури майбутніх інженерів / Вісн. Харк. держ. акад. культури : зб. наук. пр. Вип. 41. Х. : ХДАК, 2013. С. 257-261. 
[6] Денисенко Т.О., Грешнєв О. Є. Інформаційні технології в освіті / Інформаційна освіта та профессійно- комунікативні технології XXI століття: матеріали VI міжнар. наук.-практ. конф. (Одеса, 12-14 вересня 2013 р.). Одеса, 2013. С.5962.

[7] Кулакова О.М. Компонента культури в мовній комунікації інформаційного суспільства / Науковий вісник Харківського нац. пед. ун-ту ім. Г. С. Сковороди. Х., 2009. Вип. 32. С. 90-99.

[8] Мельник І.Ю. Комунікативне середовище в університетській освіті / Інформаційна освіта та професійно- комунікативні технології XXI століття: матеріали VI міжнар. наук.практ. конф. (Одеса, 12-14 вересня 2013 р.). Одеса, 2013. С.226230.

[9] Руденко Л.А. Формирование коммуникативной культуры будущих специалистов в контексте инновационной образовательной деятельности / Отечественная и зарубежная педагогика. 2014. № 3 (18). С. 114-122.

[10] Садовская В.С., Ремизов В. А. Основы коммуникативной культуры ; общ. ред. Ремизова В. А. М. : Гуманит. изд. центр ВЛАДОС, 2011. $206 \mathrm{C.}$

[11] Смирнова И.В, Смирнова О.Д. Культура коммуникационной деятельности: понятие, структура и функции / Научный вестник Дальневост. Госуд. ун-та. 2008. №5-6. С. 46-57.

[12] Сисоєва С.О., Баловсяк Н. В. Інфрормаційна компетентність фрахівця: теорія та практика формування : навч.-метод. посібник. Чернівці : Технодрук, 2006. 208 с.

[13] Філіпова Л.Я. Концепції інформаційної парадигми соціальної комунікації / Інфформаційна освіта та професійнокомунікативні технології XXI століття: матеріали VI міжнар. наук.-практ. конф. (Одеса, 12-14 вересня 2013 р.). Одеса, 2013. С.14-18.

[14] Lasen M. Education and career pathways in Information Communication Technology: What are schoolgirls saying? I Computers \& Education. 2010.54(4). C1117-1126. doi: https://doi.org/10.1016/j.compedu.2009.10.018.

[15] Louis V. Compétence communicative et saviors culturels en didactique des langues étrangeres / Université de Liege. 2006. P. 50-63.

[16] Perrenoud Ph. Compétences, langage et communication / Université de Geneve, 2000. P. 42-49.

[17] Trager G., Hall E. Culture and Communication: A Model and an Analysis // Explorations and Communication. 1994. № 3. P. 32-38.

[18] Информатизация образования: направления, средства, технологи : учебное пособие ; под общей редакцией С.И. Маслова. М.: Издательство МЭИ, 2004. 864 с.

[19] Построение информационных систем непрерывного образования на основе интернет-технологий / А.В. Дьяченко, В.Г. Манжула, А.Э. Попов и др. ; под ред. А.Э. Попова. М.: Академия естествознания, 2010. 130 с. URL:: www.monographies.ru/98. (accessed 12.12.2018)

[20] Віртуальні лабораторні системи і комплекси - нова перспектива наукового пошуку і підвищення якості підготовки фрахівців з електромеханіки / М.В. Загірняк, Д.Й. Родькін, О.П. Чорний // Електромеханічні і енергозберігаючі системи. Кременчук: КДПУ. 2009. Вип. 2/2009 (6). С. 8-12.

\section{References}

[1] Kylouskova, N. (2001). La compétence de communication. Brno, 33-38. [in French]

[2] Sherman, M.l., Bezbakh, O.M. (2014). Informatsiyna kul'tura maybutnikh inzheneriv-sudnovodiyiv yak psykholohopedahohichnyy fenomen. Zb. nauk. prats' KHNTU Aktual'ni problemy derzhavnoho upravlinnya, pedahohiky ta psykholohiyi, Iss.1 (10), 190-193. [in Ukrainian]

[3] Denderenko, O.O. (2014). Formuvannya profesiynoyi kompetentnosti sudnovoho mekhanika shlyakhom vprovadzhennya mizhdystsyplinarnoyi intehratsiyi fizychnykh znan'. Materialy Mizhnarodnoyi naukovo-praktychnoyi konferentsiyi "Aktual'ni problemy pryrodnycho-naukovoyi osvity v seredniy i vyshchyy shkoli", Kherson, 137-139. [in Ukrainian]

[4] Kolot, A. M. (2005). Motyvatsiia personal. KNEU, Kyiv. [in Ukrainian].

[5] Halatsyn, K.O. (2013). Modeliuvannia protsesu formuvannia komunikatyvnoi kultury maibutnikh inzheneriv, Journal of Kharkiv State academy of Culture, Iss. 41, 257-261. [in Ukrainian]

[6] Denysenko, T.O., Hreshniev, O.Ye. (2013). Informatsiini tekhnolohii v osviti, Informational education and professional communication technologies of XXI century: materails of VI intermational scientific conference, Odesa, September 12-14, pp. 59-62. [in Ukrainian]

[7] Kulakova, O.M. (2009), Komponenta kultury v movnii komunikatsii informatsiinoho suspilstva. Journal of Kharkiv Nat. Ped. Univ. after H. S. Skovoroda, Kharkiv, Iss. 32, 90-99. [in Ukrainian]

[8] Melnyk, I.Yu. (2013). Komunikatyvne seredovyshche v universytetskii osviti, Informational education and professional communication technologies of XXI century: materails of VI intermational scientific conference, Odesa, September 12-14, pp. 226-230. [in Ukrainian]

[9] Rudenko, L.A. (2014). Formirovanie kommunikativnoi kultury budushchikh spetsialistov $v$ kontekste innovatsionnoi obrazovatelnoi deiatelnosti. Domestic and Foreign Pedagogy Journal, № 3 (18), 114-122. [in Russian]

[10] Sadovskaya, V.S. (2011). Osnovy kommunikativnoi kultury. Moscow: VLaDOS, 206. [in Russian]

[11] Smirnova, I.V., Smirnova, O.D. (2008). Kultura kommunikatsionnoi deiatelnosti: poniatie, struktura i funktsii. Journal of Dalnevost. State University, № 5-6, 46-57. [in Russian]

[12] Sysoieva, S.O. (2006). Informatsiina kompetentnist fakhivtsia: teoriia ta praktyka formuvannia. Chernivtsi: Tekhnodruk, 208. [in Ukrainian] 
[13] Filipova, L.Ya. (2013). Kontsepcii informatsiinoi paradyhmy sotsialnoi komunikatsii, Informational education and professional communication technologies of XXI century: materails of VI intermational scientific conference, Odesa, September 12-14, pp. 14-18. [in Ukrainian]

[14] Lasen, M. (2010). Education and career pathways in Information Communication Technology: What are schoolgirls saying? Computers \& Education, 54(4), 1117-1126. doi: https://doi.org/10.1016/j.compedu.2009.10.018.

[15] Louis, V. (2006). Compétence communicative et saviors culturels en didactique des langues étrangeres. Université de Liege, pp. 50-63. [in French]

[16] Perrenoud, Ph. (2000). Compétences, langage et communication, Université de Geneve, pp. 42-49. [in French]

[17] Trager, G., Hall, E., (1994). Culture and Communication: A Model and an Analysis. Explorations and Communication, Iss. 3, 32-38. [in English]

[18] Maslova, S. (Ed.) (2004). Informatization of education: directions, facilities, technology : Textbook. Publishing House of Moscow Power Engineering Institute, Moscow, Russia, 864. [in Russian]

[19] Dyachenko, A.V., Manzhula, V.G., Popov, A.E. (Ed.), ets. (2010). Information systems of continuing education based on Internet technology. Academy of Natural Science, Moscow, 130. Available at: www.monographies.ru/98. (accessed 12.12.2018) [in Russian]

[20] Zagirnyak, M.V., Rodkin, D.Y., Chornyi, O.P. (2009). Virtual laboratory systems and complexes - a new perspective for scientific research and improving the quality of training in electro. Electromechanical and efficient system, Iss. 2 (6), 8-12. [in Ukrainian]

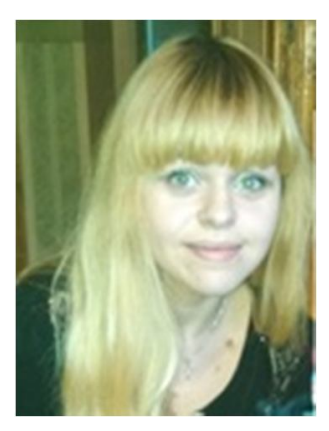

Юрженко Альона Юріївна,

спеціаліст другої категорії, викладач англійської мови,

Морський коледж Херсонської Державної Морської Академії,

вул. Робоча, 83, м. Херсон, Україна, 73001.

Тел. +380999018138. E-mail: helen18@online.ua

\section{Yurzhenko Alona Yuriivna,}

Specialist of the second degree, Teacher of English,

Maritime college of Kherson State Maritime Academy,

83 Robocha str., Kherson, Ukraine, 73001.

Tel. +380999018138. E-mail: helen18@online.ua

ORCID: 0000-0002-6560-4601

\section{Citation (APA):}

Yurzhenko, A. (2018). Pedagogical conditions for training of future ship engineers in the process of English for specific purpose learning. Engineering and Educational Technologies, 6 (4), 48-57. doi: https://doi.org/10.30929/2307-9770.2018.06.04.05

\section{Цитування (ДСТУ 8302:2015):}

Юрженко А. Ю. Педагогічні умови підготовки майбутніх суднових механіків у процесі вивчення англійської мови за професійним спрямуванням / Інженерні та освітні технологіï. 2018. Т. 6. № 4. С. 48-57. doi: https://doi.org/10.30929/23079770.2018 .06 .04 .05

Обсяг статmі: сторінок-10 ; умовних друк. аркушів - 1,149. 